\title{
Unusual in vivo turnover of transfer RNA in Vibrio cholerae
}

\author{
Partha Mukhopadhyay, Tapan Gangopadhyay and Ranajit K. Ghosh
}

Author for correspondence: Ranajit K. Ghosh. Tel: +9133473 5197. Fax: +91334730284.

Molecular Biology Laboratory, Indian Institute of Chemical Biology, 4 Raja S. C. Mullick Road, Jadavpur, Calcutta 700032, India

\begin{abstract}
Two lines of evidence suggest that, unlike in other organisms, the transfer RNAs of Vibrio cholerae undergo rapid turnover in vivo. Firstly, the tRNA content of $V$. cholerae cells treated with rifampicin (an inhibitor of initiation of RNA synthesis) decreased rapidly and continuously. Secondly, the newly synthesized tRNAs were rapidly degraded even under normal conditions of growth; the average half life of tRNA was $11.8 \mathrm{~min}$. The degradation is mediated by an enzyme(s), present in $V$. cholerae cytoplasm, that apparently degrades tRNA completely. Rapid turnover is balanced by an enhanced rate of tRNA biogenesis, which was calculated to be 2.5 times higher than that in Escherichia coli.
\end{abstract}

Keywords: Vibrio cbolerae, transfer RNA

\section{INTRODUCTION}

Intracellular RNA species can be classified into two groups, one with rapid turnover, such as messenger RNA, and the other which is quite stable and consists of ribosomal RNA and transfer RNA. Protection by ribosomal proteins can account for the stability of $r$ RNA, while that of tRNAs is attributed to their compact threedimensional structure. But under adverse conditions, such as starvation for essential nutrients like nitrogen (Ben-Hamida \& Schlessinger, 1965), carbon (Nishi et al., 1962), phosphate (Maruyama \& Mizuno, 1965; Davis $e t$ al., 1986) and magnesium (McCarthy, 1962; Natori et al., 1966), treatment with EDTA and rifampicin (Yuan \& Shen, 1975), or growth at elevated temperatures (Nozawa et al., 1967), ribosomes and rRNAs in Escherichia coli become susceptible to degradation. tRNA, however, remains essentially stable even under these conditions (Maruyama \& Mizuno, 1965; McCarthy, 1962; Natori et al., 1966; Yuan \& Shen, 1975; Davis et al., 1986; Nozawa et al., 1967). Even after exposure to drastic conditions, like ultra-violet irradiation or productive infection by bacteriophage lambda, which leads to cell death, tRNA molecules remain intact (King et al., 1986). This is also true for other prokaryotes, like Aerobacter aerogenes (Kennell \& Kotoulas, 1967) and Pseudomonas aeruginosa (Hou et al., 1966).

The compact three-dimensional structure of $t R N A$ notwithstanding, the conserved CCA sequence at the $3^{\prime}$ terminus of tRNA undergoes limited turnover in E. coli independent of the rest of the RNA chain (Deutscher $e t$ al., 1977). The defective tRNA so generated is quickly repaired by the enzyme tRNA nucleotidyltransferase (Deutscher \& Evans, 1977). Mutants lacking this enzyme accumulate defective tRNAs which are subsequently degraded by RNase D (Zhang \& Deutscher, 1988). Total yield of tRNA from such mutants is considerably lower than that from wild-type cells (Deutscher et al., 1977).

Vibrio cholerae, a Gram-negative bacterium, is the causative agent of the disease cholera. Recently, we have examined various aspects of $t R N A$ of this organism and its phages. Choleraphage $\phi 149$ and phage $e_{4}$ have been shown to induce synthesis of phage-coded tRNA molecules upon infection. These tRNAs have been characterized (Chattopadhyay \& Ghosh, 1988a; Mandal \& Ghosh, 1988), the tRNA genes have been localized on the phage genome (Chattopadhyay \& Ghosh, 1988b) and the gene clusters have been cloned (Chattopadhyay \& Ghosh, 1989). It was observed that the yields of tRNA from $V$. cholerae cells were always lower than those obtained from E. coli. We have conducted a systematic investigation of this phenomenon and report here that, unlike in other organisms, tRNAs of $V$. cholerae undergo rapid turnover in vivo. The process is mediated by a cytoplasmic nuclease(s) that can degrade intact tRNA completely.

\section{METHODS}

Bacterial strains. All $V$. cholerae strains were obtained from the National Institute of Cholera and Enteric Diseases, Calcutta. Cultures were maintained lyophilized or frozen at $-70^{\circ} \mathrm{C}$ in nutrient broth. For routine use, strains were maintained on nutrient agar slants and subcultured every two weeks. Every month strains were passaged through animals to restore 
toxinogenicity as described earlier (Roy et al., 1982a). E. coli A19 (metB1 rna) was obtained from Professor Murray Deutscher of UCON Health Centre, Farmington, USA. E. coli C-600 (thi-1 thr-1 leu-6 lac Y'1 ton A21 supE44) was used as RNase $\mathrm{I}^{+}$strain.

Media and growth conditions. Cells were grown at $37^{\circ} \mathrm{C}$ with shaking (180 r.p.m.) in nutrient broth [Bactopeptone (Difco) $10 \mathrm{~g}$, Lablemco powder (Oxoid) $10 \mathrm{~g}$ and sodium chloride $5 \mathrm{~g}$ per litre of distilled water, $\mathrm{pH} 7 \cdot 5$ ] to an $\mathrm{OD}_{540}$ of $1 \cdot 0$, harvested and washed with $0.9 \%$ sodium chloride. Cells were stored frozen at $-70^{\circ} \mathrm{C}$ prior to use for either enzyme or tRNA isolation. For isolation of $\left[{ }^{32} \mathrm{P}\right] \mathrm{tRNA}$, cells were grown in lowphosphate nutrient broth in the presence of carrier-free $\left[{ }^{32}\right.$ P]orthophosphoric acid as already described (Ghosh \& Guhathakurata, 1983).

Isolation of tRNA and diesterase-treated tRNA. Labelled and unlabelled tRNAs were isolated by the method of Ghosh \& Guhathakurata (1983). To prepare defective tRNA, $\left[{ }^{32} \mathrm{P}\right] \mathrm{tRNA}$ was treated with snake venom phosphodiesterase to remove about 3-4 residues from the 3'-termini (Ghosh \& Deutscher, 1978).

Assay of the nuclease activity. Nuclease activity was assayed in a final volume of $0.1 \mathrm{ml}$ containing $20 \mathrm{mM}$ Tris/ $\mathrm{HCl}, \mathrm{pH} 7.5$, $1 \mathrm{mM} \mathrm{MgCl}, 2$ and $\left.10 \mu \mathrm{g} \mathrm{[2}{ }^{32} \mathrm{P}\right] \mathrm{tRNA}$ or diesterase-treated tRN.A. After incubation at $37^{\circ} \mathrm{C}$ for $15 \mathrm{~min}$, the reaction was stopped by addition of $0.3 \mathrm{ml}$ carrier yeast RNA $\left(1 \mathrm{mg} \mathrm{m}^{-1}\right)$ and $0.4 \mathrm{ml}$ $20 \%(\mathrm{w} / \mathrm{v})$ trichloroacetic acid. After $30 \mathrm{~min}$ on ice, the mixture was centrifuged at $10000 \mathrm{~g}$ for $5 \mathrm{~min}$. Radioactivity in $0.4 \mathrm{ml}$ of the supernatant was measured in $10 \mathrm{ml}$ Bray's scintillation fluid [2,5-diphenyloxazole (PPO) $4 \mathrm{~g}$, (1,4 bis[2-(5-phenyloxazolyl)]benzene; 2,2'-p-phenylene-bis[5-phenyloxazole] (POPOP) $0 \cdot 2 \mathrm{~g}$, naphthalene $60 \mathrm{~g}$, methanol $100 \mathrm{ml}$, ethylene glycol $20 \mathrm{ml}$, dioxan $880 \mathrm{ml}$.

Polyacrylamide gel electrophoresis of tRNA. Electrophoresis of $\left[{ }^{32} \mathrm{P}\right] \mathrm{tRNA}$ was carried out on polyacrylamide gel slabs $(40 \mathrm{~cm} \times 20 \mathrm{~cm} \times 0.1 \mathrm{~cm})$ containing $10 \%(\mathrm{w} / \mathrm{v})$ acrylamide, $0.5 \% N, N^{\prime}$-methylene bisacrylamide and $0.1 \%$ ammonium persulfate, as described by Peacock \& Dingman (1968). Electrophoresis was carried out at $15 \mathrm{~V} \mathrm{~cm}^{-1}$ for $8 \mathrm{~h}$. Running buffer contained $89 \mathrm{mM}$ Tris base, $89 \mathrm{mM}$ boric acid, $\mathrm{pH} 8.2$, and $2.5 \mathrm{mM}$ EDTA. After electrophoresis, the gels were fixed in solution containing $10 \%(\mathrm{v} / \mathrm{v})$ acetic acid and $10 \%(\mathrm{v} / \mathrm{v})$ methanol, dried and autoradiographed.

Preparation of the cell-free extract and periplasmic supernatant. For routine assays, cells were grown to an $\mathrm{OD}_{540}$ of $1 \cdot 0$ and harvested by centrifugation. After washing with saline, cells were resuspended in $0 \cdot 1$ vol. extraction buffer containing $20 \mathrm{mM}$ Tris/ $\mathrm{HCl}, \quad \mathrm{pH} 7 \cdot 5, \quad 1 \mathrm{mM} \mathrm{MgCl}, 1 \mathrm{mM} \mathrm{DTT}, \quad 0.1 \mathrm{mM}$ phenylmethylsulphonyl fluoride and $10 \%$ (v/v) glycerol. Aliquots of $5 \mathrm{ml}$ suspension were sonicated with five $15 \mathrm{~s}$ pulses. This gave complete lysis: the $\mathrm{OD}_{540}$ of the suspension decreased by about $95 \%$ for all the strains examined. The extract was then centrifuged at $100000 \mathrm{~g}$ for $1 \mathrm{~h}$. The supernatant $(\mathrm{S} 100)$ was directly used for the appropriate assay. Periplasmic supernatant was prepared as described by Roy $e t a l$. (1982b). All procedures were carried out at $4{ }^{\circ} \mathrm{C}$.

All metabolic experiments were repeated five times and the data presented are means of these sets.

\section{RESULTS AND DISCUSSION}

\section{Yield of tRNA from various strains of $\boldsymbol{V}$. cholerae}

It was observed in this laboratory that the yield of tRNA from $I$. cholerae is lower than that from E. coli cells (see Introduction). To confirm this observation, tRNA was isolated from $I$. cholerae strains of various bio- and serotypes and with different levels of toxinogenicity grown to an $\mathrm{OD}_{540}$ of $1 \cdot 0$. The yields were compared with that from E. coli cells as obtained by us and others (Zhang \& Deutscher, 1988). E. coli cells were also grown under identical conditions. The yields of tRNA from all strains of $V$. cholerae tested were about $30 \%$ lower than those obtained from E. coli (Table 1). All $[$. cholerae strains tested, as well as the $E$. coli strains used, had similar growth rates, with a generation time of about $24 \mathrm{~min}$.

\section{Degradation of intact tRNA by cell-free extract from V. cholerae}

The presumption from the aforementioned studies is that the tRNA may be degraded in vivo in $V^{\prime}$. cholerae cells, or the rate of tRNA biogenesis is very low in this organism. Considering the inherent stability of tRNA, it may be suggested that the $3^{\prime}$-ends of tRNA in $V^{Y}$. cholerae undergo a very rapid turnover in vivo by $\mathrm{RNase} T$-like (Deutscher et al., 1985) activity. This would generate a high population of defective tRNA molecules which would be quickly degraded by $\mathrm{RNase} \mathrm{D}$-like activity present in the cytoplasm (Zhang \& Deutscher, 1988). However, the possibility of the presence of an enzyme that degrades intact $t R N A$ also cannot be ruled out.

To test these possibilities, extracts of $V$. cholerae 154 were incubated with tRNA from E. coli A19, which is known to contain intact tRNA molecules (Deutscher et al., 1977), and with tRNA from $V$. cholerae cells. As can be seen in Table 2, both the tRNAs were degraded efficiently (about $25 \%$ ) by the $[r$. cholerae extract. Complete degradation could be achieved by using 10 -fold concentrated extract (data not shown). This strongly suggests that $V$. cholerae cells contain an enzyme that can degrade intact tRNAs very efficiently. Extract from $E$. coli A19, which is known to lack such an activity (Ghosh \& Deutscher, 1978) did not degrade the above $t R N A s$. This indicates that $t R N A s$ from $I$. cholerae are not defective and are, therefore, not amenable to degradation by the RNase $\mathrm{D}$ that is present in

Table 1. Yield of tRNA from different strains of $E$. coli and $V$. cholerae

\begin{tabular}{|c|c|c|}
\hline Strain & $\begin{array}{c}\text { tRNA yield } \\
{[\mathrm{mg}(\mathrm{g}} \\
\left.\text { wet wt })^{-1}\right]\end{array}$ & $\begin{array}{c}\text { Relative } \\
\text { yield (\%) }\end{array}$ \\
\hline E. coli A19 & $2 \cdot 0$ & 100 \\
\hline E. coli C-600 & $2 \cdot 0$ & 100 \\
\hline $\mathrm{I}^{\prime}$ cbolerae $569 \mathrm{~B}^{*}$ & $1 \cdot 5$ & 75 \\
\hline $1 '$ cholerae $154 \dagger$ & $1 \cdot 45$ & 72 \\
\hline I' cbolerae Mak $757 \ddagger$ & $1 \cdot 42$ & 71 \\
\hline I'. cholerae EW6S & $1 \cdot 45$ & 72 \\
\hline
\end{tabular}


Table 2. Degradation of tRNA by extracts of $V$. cholerae and E. coli A19

${ }^{32} \mathrm{P}$-labelled intact or diesterase-treated $\mathrm{tRNAs}$ from $\mathrm{I}$. cholerce (VC) or E. coli (EC) were incubated with cell-free extracts (equivalent to $50 \mu \mathrm{g}$ protein) from these cells at $37^{\circ} \mathrm{C}$ for $15 \mathrm{~min}$ under standard assay conditions. Acid-soluble radioactivity was determined as described in Methods. The degradation was linear during the entire incubation time for each experiment.

\begin{tabular}{|lcc|}
\hline Substrate & \multicolumn{2}{c|}{$\begin{array}{c}\text { Percentage degradation by } \\
\text { extracts from: }\end{array}$} \\
\cline { 2 - 3 } & V. cholerae & E. coli \\
\hline Intact tR.N $($ VC) & 20 & $1 \cdot 8$ \\
Defective tRNA (VC) & 23.2 & $6 \cdot 3$ \\
Intact tR.N A (EC) & 22.8 & $0 \cdot 78$ \\
Defective tRNA (EC) & 24.5 & $7 \cdot 6$ \\
\hline
\end{tabular}

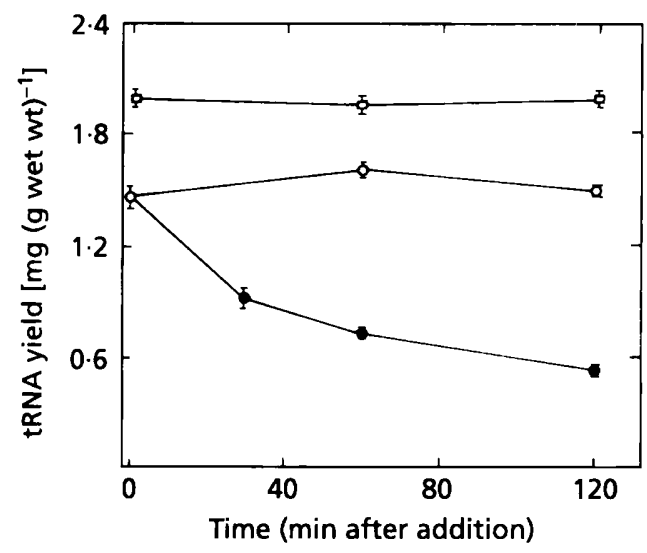

Fig. 1. tRNA content of rifampicin-treated $V$. cholerae (O) and E. coli A19 ( $\square)$ cells. Cells were grown to an $O_{540}$ of 0.2 . Rifampicin $\left(20 \mu \mathrm{g} \mathrm{ml}^{-1}\right)$ was then added to each flask. After varying periods of incubation at $37^{\circ} \mathrm{C}$, samples were removed for tRNA isolation. An untreated $V$. cholerae culture served as control (O). The bars represent SD.

E. coli. Defective tRNAs produced by treatment with snake venom phosphodiesterase are degraded by E. coli cells (Ghosh \& Deutscher, 1978), and more rapidly by $V$. cholerae cells. Periplasmic supernatant of $V$. cholerae cells failed to hydrolyse any of the above tRNAs to an appreciable extent, whereas $\left[{ }^{32} \mathrm{P}\right] \mathrm{rRNA}$ or $\left[{ }^{3} \mathrm{H}\right]$ poly $(\mathrm{A})$ was easily digested. This indicates that although the periplasm of $V$. cholerae contains a ribonuclease, the activity cannot degrade intact tRNA molecules ( $T$. Gangopadhyay \& R. K. Ghosh, unpublished observation). The enzyme(s) that degrades tRNA must therefore be located in the cytoplasm. It is important to mention that it is not yet known whether the enzyme is specific for tRNA; establishing this must await purification of the enzyme. Use of E. coli C600 instead of E. coli A19 gave identical results. Hence, in all subsequent experiments $E$. coli $\mathrm{C} 600$ was used.

\section{Degradation of tRNA in rifampicin-treated cells}

To ascertain the contribution of the putative tRNAdegrading activity to the observed lower yield of tRNA, we made use of the antibiotic rifampicin, which is known to abolish tRNA synthesis. Incubation of $V$. cholerae cells with this antibiotic for various lengths of time and determination of the tRNA content under each of these conditions should give information about the in vivo role of the degrading enzyme(s). $V$. cholerae 154 cells grown to mid-exponential phase were incubated for $2 \mathrm{~h}$ in the presence of rifampicin. Samples were withdrawn at various times for isolation of tRNA. As can be seen in Fig. 1 , the amount of tRNA in $V$. cholerae cells decreased continually over a period of $2 \mathrm{~h}$. The amount of tRNA recovered from $E$. coli cells treated identically remained unchanged for $4 \mathrm{~h}$, a phenomenon which has also been reported by others (Yuan \& Shen, 1975; Nozawa et al., 1967; Kennell \& Kotoulas, 1967; Hou et al., 1966; Deutscher et al., 1977). Cells of both the strains did not lyse at the concentration of rifampicin $\left(20 \mu \mathrm{g} \mathrm{ml}^{-1}\right)$ used. Untreated $V$. cholerae cells also maintained a steady-state level of tRNA throughout the period of incubation. This strongly suggests that the steady-state level (about $1.45 \mathrm{mg} \mathrm{g}^{-1}$ ) of $V$. cholerae $\mathrm{RNA}$ is a balance between net synthesis and breakdown; when synthesis is arrested, the tRNA level decreases due to the breakdown of tRNAs by the putative enzyme(s).

\section{Fate of newly synthesized tRNA in $V$. cholerae cells}

It may be argued that rifampicin treatment has an adverse effect on the metabolic environment such that tRNAs become accessible to various nucleases. In normal cells, these molecules may be separated from the enzyme(s) that degrade(s) tRNAs. We thus examined the fate of newly synthesized tRNA molecules in $V$. cholerae cells under normal growth conditions.

$V$. cholerae 154 cells were grown to mid-exponential phase in low-phosphate medium. The cells were labelled with $\left.{ }^{32} \mathrm{P}\right]$ orthophosphoric acid for $30 \mathrm{~min}$, then washed and transferred to prewarmed high-phosphate medium without $\left[{ }^{32} \mathrm{P}\right]$ orthophosphoric acid and incubated as usual. The $\left.{ }^{32} \mathrm{P}\right] \mathrm{tRN}$ A of these cells was then chased for $30 \mathrm{~min}$. Around $80 \%$ of the label in $V$. cholerae $\mathrm{tRNA}$ disappeared during the $30 \mathrm{~min}$ chase while that of $E$. coli tRNA remained unchanged under identical conditions (Fig. 2a). These results strongly suggest that tRNA molecules in $V$. cholerae undergo very rapid turnover: the average half life of tRNA was $11.8 \mathrm{~min}$. The rate of tRNA degradation was calculated to be $0.0827 \mathrm{mg} \mathrm{min}^{-1}$ (g wet wt) ${ }^{-1}$ [rate $=1.45-1.45 \times 2^{-1 / 11.8}$, where $\mathrm{tRNA}$ per unit biomass $=$ 1.45 and half life of tRNA $=11.8 \mathrm{~min}]$. From the logarithmic plot (Fig. 2a, inset) the decay rate constant was found to be $0.0589 \mathrm{~min}^{-1}$. That the observed degradation was solely due to tRNA was confirmed by running aliquots of tRNA after $0 \mathrm{~min}$ and $30 \mathrm{~min}$ chase on polyacrylamide gel followed by autoradiography. As expected, the bands due to tRNA almost disappeared in $30 \mathrm{~min}$ for $V$. cholerae cells (Fig. $2 \mathrm{~b}$ ). The specific activity of tRNA [c.p.m. (mg tRNA) ${ }^{-1}$ ] decreased from 7-8 $\times 10^{7}$ 
(a)

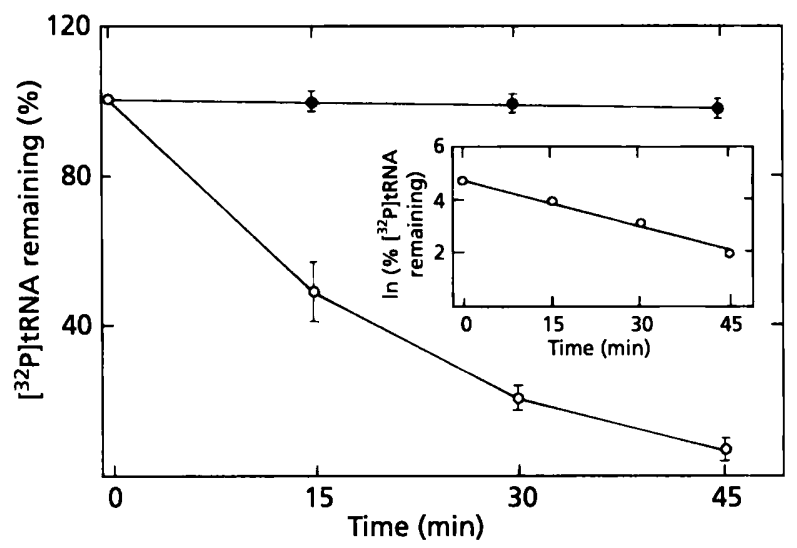

(b)

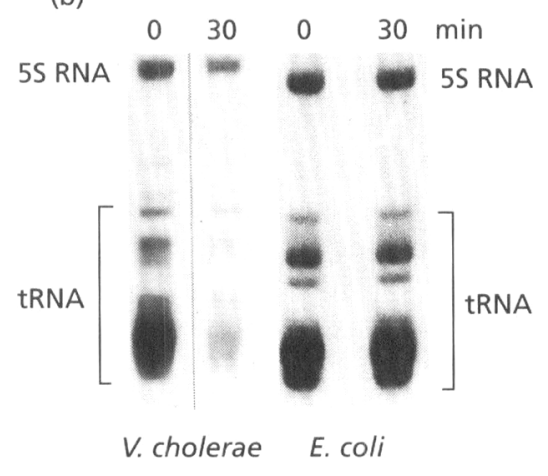

Fig. 2. (a) Fate of newly synthesized tRNA in $V$. cholerae $(O)$ and E. coli $\mathrm{C} 600(0)$ cells. Cells were grown to an $\mathrm{OD}_{540}$ of 0.2 in $25 \mathrm{ml}$ low-phosphate medium. Each flask then received $1 \mathrm{mCi}$ (37 MBq) carrier-free [32P]orthophosphate. After $30 \mathrm{~min}$ incubation at $37^{\circ} \mathrm{C}$, cells were harvested and transferred to $25 \mathrm{ml}$ nutrient broth (high phosphate). After varying periods of incubation at $37^{\circ} \mathrm{C}$, samples were withdrawn for tRNA isolation. The total amount of [32P]tRNA present in each of these isolates was determined. The bars represent SD. The inset is a logarithmic plot against time. (b) Autoradiograph of newly synthesized tRNA in samples from $0 \mathrm{~min}$ and $30 \mathrm{~min}$ chase of the experiment in (a). Total tRNA preparation from $25 \mathrm{ml}$ culture was dissolved in a final volume of $1 \mathrm{ml}$, and $10 \mu \mathrm{l}$ used for each time point. Each set contained equal amounts of $A_{260}$ material.

to $5-7 \times 10^{6}$ in $30 \mathrm{~min}$. As there was almost equivalent disappearance of all bands it may be concluded that the putative enzyme(s) do(es) not discriminate between various tRNA species. tRNA from $E$. coli cells treated identically remained unchanged as expected (Fig. 2a, b).

The results presented above indicate that tRNA in $V$. cholerae undergoes very rapid turnover in vivo - a phenomenon so far unknown in any other prokaryote. The mechanism of rapid in vivo degradation of tRNA in $V$. cholerae is very difficult to speculate upon at this stage; its elucidation must await purification of the putative degrading activities.

The observed rapid turnover of tRNAs in $V$. cholerae cells would call for an enhanced rate of tRNA biogenesis to maintain the steady-state intracellular level of
$1.45 \mathrm{mg}$ (g wet wt) $)^{-1}$. In the absence of any degradation this steady-state level would have required a synthesis rate of $0.0423 \mathrm{mg} \mathrm{min}^{-1}\left(\mathrm{~g}\right.$ wet wt) ${ }^{-1}$ [rate $=1.45 \times 2^{1 / 24}$ -1.45 ] for a generation time of $24 \mathrm{~min}$. Compensating for the observed rate of decay $\left[0.0827 \mathrm{mg} \mathrm{min}^{-1}\right.$ (g wet wt) ${ }^{-1}$ of the cell; Fig. 2a] the actual rate of tRNA synthesis in $V$. cholerae would be $0.125 \mathrm{mg} \mathrm{min}^{-1}$ $(\mathrm{g} \text { wet } \mathrm{wt})^{-1}$. The rate of tRNA biogenesis in $E$. coli cells grown under identical conditions would be $0.0584 \mathrm{mg} \mathrm{min}^{-1}$ (g wet wt) ${ }^{-1}$ [rate $=2 \times 2^{1 / 24}-2$; where tRNA yield per biomass was $2 \mathrm{mg}\left(\mathrm{g}\right.$ wet wt) ${ }^{-1}$ and generation time was $24 \mathrm{~min}]$. Thus, $V$. cholerae cells apparently synthesize tRNA at a rate about 2.5 times that of E. coli cells.

The rapid degradation of tRNA and its enhanced rate of synthesis raise a couple of interesting points. First, why the cell should adopt such an uneconomic process is difficult to understand. Isolation and analysis of mutants deficient in this enzyme(s) should throw some light on its significance. Second, rapid synthesis implies a high rate of transcription of $\mathrm{tRNA}$ gene clusters as well as the presence of an elevated level of tRNA-processing activity in $I^{\prime}$. cholerae cells.

$V$. cholerae is the host for a large number of lytic phages. Like $\mathrm{T}_{4}$ and $\mathrm{T}_{5}$ phages of E. coli, two of the choleraphages, namely phages $\phi 149$ and $e_{4}$, induce synthesis of phagecoded tRNA molecules upon infection (Chattopadhyay \& Ghosh, 1988a; Mandal \& Ghosh, 1988). With respect to the E. coli phages it was suggested that phage-coded tRNAs are not essential for phage development as phage mutants lacking tRNA genes are viable (Wilson et al., 1972). However, in view of the rapid turnover of host tRNA in $V$. cholerae, the tRNA genes of cholera phages may play a very significant role in phage development.

\section{ACKNOWLEDGEMENTS}

P.M. and T.G. are grateful to the Council of Scientific and Industrial Research for the award of a Senior Research Fellowship and a Pool Officer position, respectively.

\section{REFERENCES}

Ben-Hamida, F. \& Schlessinger, D. (1965). Synthesis and breakdown of ribonucleic acid in Escherichia coli starving for nitrogen. Biochim Biopbys Acta 119, 183-191.

Chattopadhyay, S. \& Ghosh, R. K. (1988a). Characterization of phage-specific transfer RNA molecules coded by l'ibrio eltor phage $\mathrm{e}_{4}$. I irology 165, 606-608.

Chattopadhyay, S. \& Ghosh, R. K. (1988b). Localization of the transfer RNA gene on the physical map of L'ibrio eltor phage $e_{4}$ genome. I'irology 162, 337-345.

Chattopadhyay, S. \& Ghosh, R. K. (1989). The cloning and

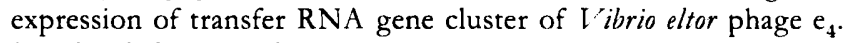
I'irology 171, 114-119.

Davis, B. D., Luger, S. M. \& Tai, P. C. (1986). Role of ribosome degradation in the death of starved Escherichia coli cells. $J$ Bacteriol 166, 439-445.

Deutscher, M. P. (1990). Ribonucleases, tRNA nucleotidyl transferase, and the $3^{\prime}$ processing of tRNA. Prog Nucleic Acid Res Mol Biol 39, 439-445. 
Deutscher, M. P. \& Evans، J. A. (1977). Transfer RNA nucleotidyl transferase repairs all transfer RNA randomly. $J$ Mol Biol 109, 593- 597.

Deutscher, M. P., Lin, J. J.-C. \& Evans, J. A. (1977). Transfer RNA metabolism in Eschericbia coli cells deficient in tRNA nucleotidyl transterase. J Mol Biol 117, 1081-1094.

Deutscher, M. P., Marlor, C. W. \& Zaniewski, R. (1985). RNase T is responsible for the end turnover of $\mathrm{tRNA}$ in Escherichia coli. Proc Natl. Acad Sci US.A 82, 6427-6430.

Ghosh, R. K. \& Deutscher, M. P. (1978). Identification of an Eschierichia coli nuclease acting on structurally altered transfer RNA molecules. J Biol Chem 253, 997-1000.

Ghosh, R. K. \& Guhathakurata, I. (1989). Synthesis of phagespecific transfer RNA molecules by vibriophage $\phi 149$. FEBS Lett 162, 177-179.

Hou, C. I., Gronlund, A. F. \& Campbell, J. J. R. (1966). Influence of phosphate starvation on cultures of Pseudomonas aeruginosa.J Bacteriol 92, 851-855.

Kennell, D. \& Kotoulas, A. (1967). Magnesium starvation of Aerobacter aerogenes. I. Changes in nucleic acid composition. $J$ Bacteriol 93, 334-344.

King, T. C., Sirdeskmukh, R. \& Schlessinger, D. (1986). Nucleolytic processing of ribonucleic acid transcripts in prokaryotes. Microbiol Rer 50, 428-451.

McCarthy, B. J. (1962). The effects of magnesium starvation on the ribosome content of Escherichia coli. Biocbim Biophys Acta 55, 880888.

Mandal, N. \& Ghosh, R. K. (1988). Characterization of phagespecitic transfer RNA molecules coded by I 'ibrio eltor $\mathrm{e}_{4}$. I'irology 166, 583-585.

Maruyama, H. \& Mizuno, D. (1965). The participation of ribonuclease in the degradation of Eschericbia coli ribosomal ribonucleic acid as revealed by oligonucleotides accumulation in the phosphorus-deficient stage. Biocbim Biophys Acta 119, 183-191.

Natori, S., Nozawa, R. \& Mizuno, D. (1966). The turnover of ribosomal RNA of Escherichia coli in a magnesium-deficient stage. Biocbim Biopbys Acta 114, 245-253.

Nishi, A., Okamura, S. \& Yonagita, T. (1967). Shift of cell-age distribution in the later phase of Escherichia coli culture. $J$ Gen Appl Microbiol 13, 103-119.

Nozawa, R., Horiuchi, T. \& Mizuno, D. (1967). Degradation of ribosomal RNA in a temperature sensitive Escherichia coli. Arch Biocbem Biopbys 118, 402-409.

Peacock, A. C. \& Dingman, C.W. (1968). Molecular weight estimation and separation of ribonucleic acid by electrophoresis in agarose-acrylamide composite gels. Biochemistry 7, 668-674.

Roy, N. K., Das, G., Balganesh, T. S., Dey, S. N., Ghosh, R. K. \& Das, J. (1982a). Enterotoxin production, DNA repair and alkaline phosphatase of $\mathrm{I}$ ibrio cholerae before and after animal passage. J Gen Microbiol 128, 1927-1932.

Roy, N. K., Ghosh, R. K. \& Das, J. (1982b). Monomeric alkaline phosphatase of L'ibrio cbolerae. J Bacteriol 150, 1033-1039.

Wilson, J. H., Kim, J. S. \& Abelson, J. N. (1972). Bacteriophage ' $T_{4}$ transfer RNA. III. Clustering of the genes for $\mathrm{T}_{4}$ transfer RNA's. $J$ Mol Biol. 71, 547-556.

Yuan, D. \& Shen, V. (1975). Stability of ribosomal and transfer ribonucleic acid in Eschericbia coli $\mathrm{B} / \mathrm{r}$ after treatment with ethylenedinitrilotetraacetic acid and rifampicin. $J$ Bacteriol 122, 425-432.

Zhang, J. \& Deutscher, M. P. (1988). Transfer RNA is a substrate of $\mathrm{R}$ Nase $\mathrm{D}$ in vivo. J Biol Chem 263, 17909-17912.

Received 14 September 1993; revised 7 January 1994; accepted 31 January 1994. 